\title{
Application of the "real options theory" method to the production systems used in dairy cattle farming
}

\author{
[Aplicação do método "Teoria das Opções Reais" nos sistemas de produção utilizados \\ na bovinocultura leiteira] \\ D.T. Xavier ${ }^{1}$, A.A.C. Peres $^{2}$, G.L. Almeida ${ }^{2}$, C.A.B. Carvalho ${ }^{1}$ \\ ${ }^{1}$ Universidade Federal Rural do Rio de Janeiro - Seropédica, RJ \\ ${ }^{2}$ Universidade Federal Fluminense - Volta Redonda, RJ
}

\begin{abstract}
The objective of this study was to analyze applications of real options theory for increasing the productivity of Mantiqueira ecotype dairy cows kept in guinea grass pastures with different sources of bulky supplementation (black oats, fodder cane, or sorghum silage), because the traditional methodologies do not consider the uncertainties related to this activity. Real options theory, an investment evaluation method, fills this gap as its most significant feature is its flexibility to act on uncertain events. Based on the results obtained for two economic indicators, the net present value and internal rate of return, and considering the production items identified in the sensitivity analysis, this study evaluated the expansion flexibility of each system using the real options theory methodology in discrete time as proposed by Copeland and Antikarov (2001). The analysis of the expansion options showed that the values of the production systems increased by $6.73 \%, 1.21 \%$, and $19.49 \%$ for the systems supplemented with sorghum silage, black oats, and fodder cane, respectively. The expanded net present values were $\mathrm{R} \$ 141,642.39, \mathrm{R} \$ 64,211.08$, and $\mathrm{R} \$ 58,013.07$ for the systems that adopted bulky supplementation with black oats, fodder cane, and sorghum silage, respectively.
\end{abstract}

Keywords: economic-financial analysis, economic indicators, milk production

\section{RESUMO}

Objetivou-se analisar a aplicação da Teoria das Opções Reais para expansão da produtividade de vacas leiteiras do ecótipo Mantiqueira, mantidas em pastagem de capim-Mombaça com fornecimento de diferentes fontes de suplementação volumosa (aveia-preta, cana-forrageira ou silagem de sorgo), uma vez que as metodologias tradicionais não consideram as incertezas presentes na atividade. A Teoria de Opções Reais é um método de avaliação de investimento que possui como maior característica a valoração da flexibilidade de agir a eventos incertos, preenchendo, assim, a lacuna deixada pelo método tradicional. A partir dos resultados obtidos pelos indicadores econômicos valor presente líquido e taxa interna de retorno, em conjunto com os itens de produção identificados na análise de sensibilidade, foi possível avaliar o valor da flexibilidade de expansão que cada sistema apresentou. A flexibilidade de expansão foi avaliada utilizando-se a metodologia Teoria das Opções Reais, proposta por Copeland e Antikarov (2001), em tempo discreto. $O$ resultado da análise da opção de expansão apresentou aumento nos valores dos sistemas de produção, na ordem de 6,73\%, 1,21\% e 19,49\%, para os sistemas suplementados com silagem de sorgo, aveia-preta e cana-forrageira, respectivamente. Os resultados obtidos para os valores presentes líquidos expandidos foram de $R \$ 141.642,39, R \$ 64.211,08$ e $R \$ 58.013,07$, para os sistemas que adotaram a suplementação volumosa com aveia-preta, cana-forrageira e silagem de sorgo, respectivamente.

Palavras-chave: análise econômico-financeira, indicadores econômicos, produção de leite

Recebido em 2 de março de 2020

Aceito em 27 de julho de 2020

E-mail: deyxavier@outlook.com 


\section{INTRODUCTION}

Dairy farming is very common in Brazil. According to the Agricultural Census (Censo..., 2006), Brazil has 1.3 million dairy farms. In 2016, Brazil was the fifth largest milk producer in the world, with an estimated production of 35 billion liters, or around $\mathrm{R} \$ 39$ billion in value (Pesquisa..., 2017). In 2017, global milk production reached 827.9 billion liters, and Brazil contributed 33.5 billion liters (Anuário..., 2019). However, the financial margins in the sector are small and subject to market uncertainties, such as fluctuations in the prices of raw materials, products, and inputs. Furthermore, the production volume of dairy farming depends on edaphicclimatic conditions. These uncertainties directly affect producers' decisions.

Traditional investment evaluation methodologies (e.g., the discounted cash flow technique) fail to account for the impact of these uncertainties on dairy farm production cash flows. In contrast, the real options theory (ROT) methodology considers existing managerial and operational flexibilities in the presence of uncertainty. The ROT methodology measures the value of the option to invest, contemplates managerial flexibility in the evaluation of investments, and uses option pricing methods for this evaluation (Nardelli, 2009).

According to Dixit and Pindyck (1994), the main concepts associated with ROT are irreversibility, uncertainty, and flexibility in changing the initial strategy of the project. Nardelli (2009) claimed that ROT is the best approach for evaluating projects that have significant operational and strategic options, as it can integrate strategy and finance. Thus, the objective of this study was to analyze the application of ROT to expanding the productivity of the different production systems used in dairy cattle farming. The analysis was based on the intensive use of guinea grass pasture, with the supply of black oats, fodder cane, or sorghum silage as bulky supplementation during the dry period of the year.

\section{MATERIALS AND METHODS}

This study was carried out based on zootechnical and economic data published by Peres (2006), who evaluated three production systems applied to dairy cattle farming with the intensive use of guinea grass pasture and the supply of different sources of bulky supplementation (i.e., black oats, fodder cane, and sorghum silage). Peres's (2006) study provided numerical inputs for constructing a model applying ROT, which represented the data treatment of this study following the methodology proposed by Paddock et al. (1988). For the construction of the model and characterization of the different production systems, the net present value (NPV) investment appraisal technique was used, along with the production items identified in a sensitivity analysis.

Peres' (2006) data were obtained from the Vale do Paraíba Regional Pole belonging to the São Paulo Agribusiness Technology Agency (APTA), located in the city of Pindamonhangaba, São Paulo. The data covered the period from October 2003 to September 2005. From these data, a survey of economic and cash flow information was carried out and used to characterize the different production systems that were analyzed.

Different production systems were evaluated for lactating cows managed in guinea grass pastures and receiving different sources of bulky supplementation during the dry season. Specifically, these sources were pastures of black oats; chopped fodder cane and added urea, supplied in the trough; and sorghum silage, supplied in the trough daily. Initially, the production system contained 60 dairy cows in the lactation stage, separated into two production lots. In the first two years of assessment, 36 cows were managed in the rainy season and 24 in the dry season. The data for subsequent years were projected according to the zootechnical and economic indicators recorded in the experimental period (October 2003 to September 2005), based on the disposal of cows and the acquisition of new matrices over time, and considering that at the cows would demonstrate the same behavior in the reproductive and productive cycles. The financial data were updated using the General Price Index Internal Availability (IGP-DI) published by Fundação Getúlio Vargas (Índices..., 2019).

The starting point for the analysis was the project's NPV without flexibility, calculated using the traditional cash flow method. The NPVs found by Peres (2006) for systems supplemented with black oats, fodder cane, and sorghum silage, assuming a $6 \%$ discount rate, were $\mathrm{R} \$$ 132,509.84, R\$ 63,446.07, and $\mathrm{R} \$ 48,439.97$, 
respectively. Peres (2006) also performed a sensitivity analysis and found that the selling price of milk had the most negative impact on the indicators of the systems evaluated. ROT fills the gaps in the discounted cash flow method by considering investment projects not as an obligation, but as a right. The result of real options is the value of flexibility in changing the design. There are three traditional techniques for calculating options in investment projects:Black Scholes model, Monte Carlo simulation, and binomial model.

A binomial model using the risk-neutral probability method was used to calculate the option values. The expansion option was calculated, and Copeland and Antikarov's (2001) methodology was used to evaluate the options. In this analysis, two modules were considered. The original project (Module 1) produced 15,780, $13,556.29$, and 14,637 liters of type B milk, on average, for the black oat, fodder cane, and sorghum silage systems, respectively, over a twelve-year horizon.

Module 2 aimed at analyzing the expansion of milk production capacity by $100 \%$, thus doubling the structure needed for increased productivity to maximize the potential of the available infrastructure - that is, to use the maximum capacity of the improvements, machines, equipment, and labor. This condition is possible only since the infrastructure used in dairy activities was found to be underused, because the composition of the cash flow for the ROT study considered the results of the production systems - using 36 dairy cows of the Mantiqueira ecotype in the spring-summer period and 24 dairy cows in the autumn-winter period (Guaragna et al., 1984).

As the inventory was carried out to evaluate the available infrastructure of the farm it was found that improvements and machines were being underutilized, since the milk production of only the experimental cows was considered and not that of the whole herd. To apply ROT, it is necessary to construct an event tree, which does not incorporate decisions. In an event tree, a discrete random path with two states, $u(u p)$ and $d$ (down), is used. These states are represented by equations 1 and 2, respectively, which correspond to the high and low prices of the production item, considering the probability of occurrence and the volatility.

$$
\begin{aligned}
& u=e^{\sigma \sqrt{\Delta t}} \\
& d=\frac{1}{u}
\end{aligned}
$$

The volatility (i.e., the annualized standard deviation of the distribution of returns of a project under uncertainty) was calculated from the primary uncertainty identified in the production systems using the results obtained from the sensitivity analysis. In this case, the price of milk had the greatest influence on the results of the indicators, given the price fluctuations that occurred in the market. Then, the historical series of prices for commercial milk in São Paulo between January 2005 and December 2018 were considered to calculate the volatility. These prices were obtained from the Centre for Advanced Studies in Applied Economics of Escola Superior de Agricultura Luiz Queiroz/Universidad de São Paulo (ESALQ/USP). All prices during the study period were deflated by applying the IGP-DI published by FGV, with December and 2018 as the reference month and year, respectively (Índices..., 2019).

To turn the event tree into a decision tree, the management decisions made at the nodes of the event tree are determined using risk-neutral probabilities. Equations 3 and 4 determine the upward $u$ and downward $d$ movements and their risk-neutral probabilities, $p$ and 1-p, respectively, according to the risk-free interest rate $(r)$ and the project volatility $(\sigma)$.

$$
\begin{aligned}
& p=\frac{e^{r \Delta t}-d}{u-d} \\
& 1-p
\end{aligned}
$$

The option value is calculated by working backwards. In the last period, the cash flow value was the maximum of the option value $\left({ }_{s u}\right.$ or $\left.S_{d}\right)$ and zero; thus, each cell in the last column was determined by equations 5 and 6 :

$$
\begin{aligned}
& \operatorname{Max}\left[S_{u}-X, 0\right] \\
& \operatorname{Max}\left[S_{d}-X, 0\right]
\end{aligned}
$$

When the present value of the production system calculated at the corresponding node of the event tree is greater than the invested value, the option must be exercised; otherwise, the option has a 
value of zero and must not be exercised. Once the option values were calculated, the decision tree was assembled using these values to observe the decisions to be made. The expanded NPV (i.e., the sum of the NPV and the option value) is expressed by equation 7 .

$$
\begin{aligned}
& \text { Expanded NPV }=\text { Traditional NPV }+ \\
& \text { Value from Option }
\end{aligned}
$$

\section{RESULTS AND DISCUSSION}

The NPVs of the underlying asset subject to risk determined by the analysis were $\mathrm{R} \$ 132,509.84$, $\mathrm{R} \$ 63,446.07$, and $\mathrm{R} \$ 48,439.97$ for the systems supplemented with black oats, fodder cane, and sorghum silage, respectively. Total initial investments of around $\mathrm{R} \$ 245,845.40, \mathrm{R} \$$ $198,491.72$, and $\mathrm{R} \$ 215,653.88$ were sufficient for improvements, machines, and equipment for the systems supplemented with black oats, fodder cane, and sorghum silage, respectively, for module 1. For module 2, investments of $\mathrm{R} \$$ 369,308.36, $\mathrm{R} \$ 267,763.62$, and $\mathrm{R} \$ 308,068.24$, respectively, were necessary to promote the expansion of production systems.
The volatility $(\sigma)$ was determined to be $17.14 \%$. Based on this value and the risk-free rate $(r)$, which is the Selic rate of $6.50 \%$ per year (Taxa..., 2019), the values of $u$ and $d$ were calculated to be 1.19 and 0.84 , respectively. The risk-neutral probability of upward movement $(p)$ was approximately $64 \%$, and that of downward movement (1-p) was $36 \%$. These variables were used to construct the trees used to calculate the expansion option over a 12 -year time horizon. In the event trees (Table 1, 3 and 5), under totally favorable conditions for the NPVs of the production systems that use black oats, fodder cane, and sorghum silage as bulky supplements to achieve the maximum probability and volatility, the returns on these systems could reach $\mathrm{R} \$$ 1,036,300.00, $\mathrm{R} \$ 496,205.55$, and $\mathrm{R} \$ 378,844.30$, respectively, in the 12 th year.

The values generated by the event tree were compared, node by node, in the decision trees in Table 2, 4, and 5, which reflect the production systems supplemented with black oats, fodder cane, and sorghum silage, respectively. The values of the last nodes in the 12th year of exploration of the activity were calculated using the risk-free Selic interest rate of $6.5 \%$.

Table 1. Event tree of a Mantiqueira ecotype dairy cattle farm, with intensive use of Mombasa grass pasture supplemented with black oats, for a period of 12 years (values in $\mathrm{R} \$ 10,000.00$ ). Constructed using the real options theory.

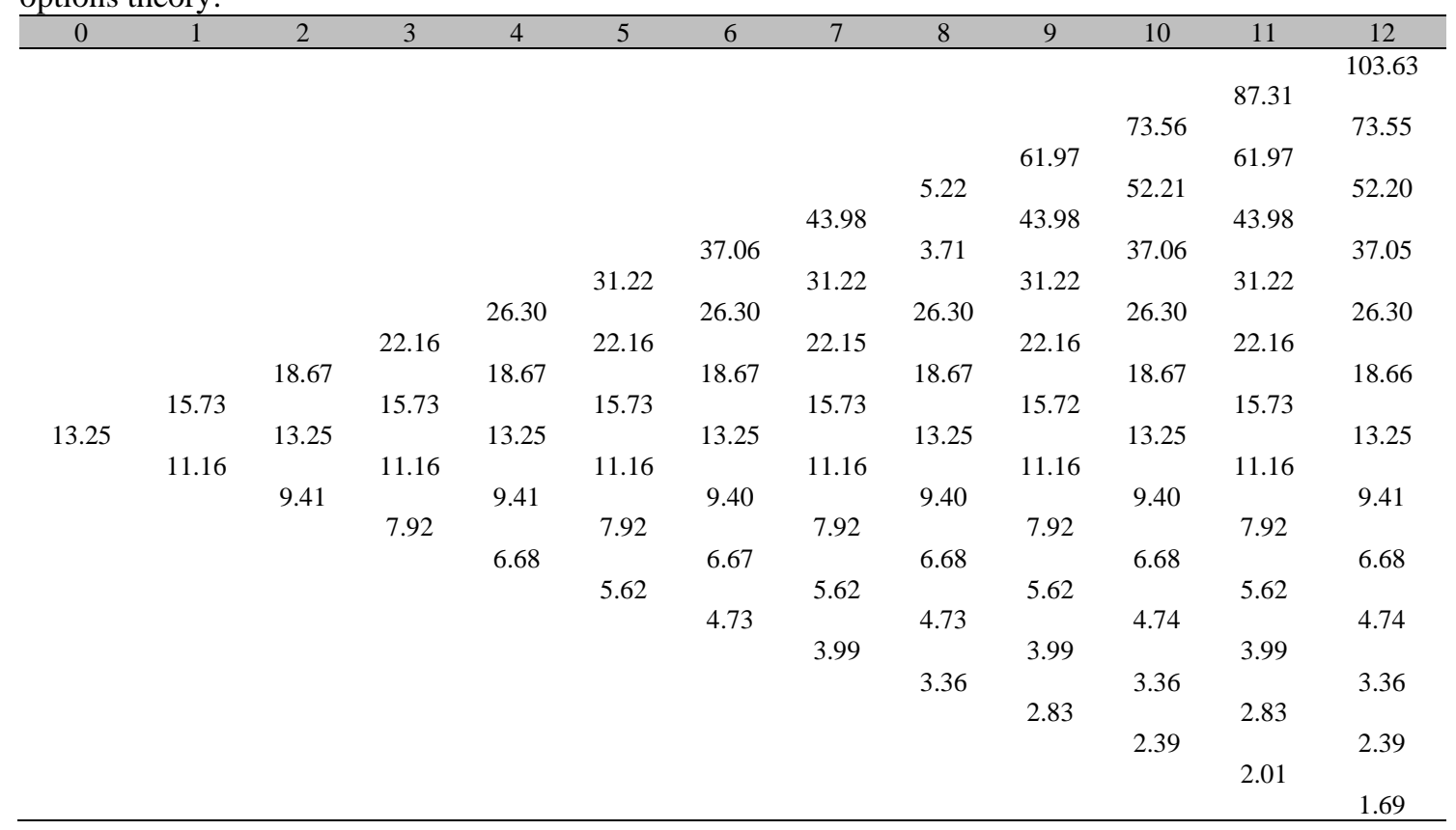




\section{Xavier et al.}

Table 2. Decision tree of a Mantiqueira ecotype dairy cattle farm, with intensive use of Mombasa grass pasture supplemented with black oats, for a period of 12 years (values in $\mathrm{R} \$ 10,000.00$ ). Constructed using the real options theory.

\begin{tabular}{|c|c|c|c|c|c|c|c|c|c|c|c|c|}
\hline 0 & 1 & 2 & 3 & 4 & 5 & 6 & 7 & 8 & 9 & 10 & 11 & 12 \\
\hline \multirow{19}{*}{4.84} & \multirow{19}{*}{$\begin{array}{l}5.75 \\
4.08\end{array}$} & \multirow{19}{*}{$\begin{array}{l}6.82 \\
4.84 \\
3.44\end{array}$} & \multirow{10}{*}{$\begin{array}{l}8.10 \\
5.75\end{array}$} & \multirow{8}{*}{9.61} & \multirow{7}{*}{11.41} & \multirow[b]{6}{*}{13.55} & \multirow[b]{5}{*}{16.08} & \multirow{5}{*}{19.09} & & & & 37.88 \\
\hline & & & & & & & & & & & 31.92 & \\
\hline & & & & & & & & & & 26.89 & & 26.89 \\
\hline & & & & & & & & & 22.65 & 19.09 & 22.65 & 19.09 \\
\hline & & & & & & & & & 16.08 & & 16.08 & \\
\hline & & & & & & & \multirow{2}{*}{11.41} & 13.55 & & 13.55 & & 13.55 \\
\hline & & & & & & 9.61 & & 9.61 & 11.41 & 9.61 & 11.41 & 9.61 \\
\hline & & & & & 8.10 & & 8.10 & \multirow[b]{2}{*}{6.82} & 8.10 & & 8.10 & \multirow[b]{2}{*}{6.82} \\
\hline & & & & 6.82 & 575 & 6.82 & 575 & & 575 & 6.82 & & \\
\hline & & & & \multirow{2}{*}{4.84} & & 4.84 & & \multirow{2}{*}{4.84} & & 4.84 & & \multirow[t]{2}{*}{4.84} \\
\hline & & & 4.08 & & 4.08 & & 4.08 & & 4.08 & & 4.08 & \\
\hline & & & & \multirow[t]{2}{*}{3.44} & & 3.44 & & \multirow[t]{2}{*}{3.44} & & 3.44 & & \multirow[t]{2}{*}{3.44} \\
\hline & & & 2.90 & & 2.90 & & 2.90 & & 2.90 & & 2.90 & \\
\hline & & & & 2.44 & 2.06 & & \multirow[t]{2}{*}{2.06} & 2.44 & 2.06 & & 2.06 & 2.44 \\
\hline & & & & & & 1.73 & & 1.73 & & 1.73 & & \multirow[t]{2}{*}{1.73} \\
\hline & & & & & & & \multirow[t]{2}{*}{1.45} & \multirow{2}{*}{1.23} & 1.45 & & 1.45 & \\
\hline & & & & & & & & & 1.04 & 1.25 & 1.04 & 1.23 \\
\hline & & & & & & & & & & 0.87 & 073 & 0.87 \\
\hline & & & & & & & & & & & & 0.62 \\
\hline
\end{tabular}

Table 3. Event tree of a Mantiqueira ecotype dairy cattle farm, with intensive use of Mombasa grass pasture supplemented with fodder cane, for a period of 12 years (values in $\mathrm{R} \$ 10,000.00$ ). Constructed using the real options theory.

\begin{tabular}{|c|c|c|c|c|c|c|c|c|c|c|c|c|}
\hline 0 & 1 & 2 & 3 & 4 & 5 & 6 & 7 & 8 & 9 & 10 & 11 & 12 \\
\hline \multirow{20}{*}{6.34} & \multirow{20}{*}{$\begin{array}{l}7.53 \\
5.34\end{array}$} & \multirow{20}{*}{$\begin{array}{l}8.93 \\
6.34 \\
4.50\end{array}$} & \multirow{8}{*}{10.61} & \multirow[b]{7}{*}{12.59} & \multirow[b]{6}{*}{14.95} & \multirow[b]{5}{*}{17.74} & \multirow[b]{4}{*}{21.06} & \multirow{3}{*}{24.99} & & \multirow{2}{*}{\multicolumn{2}{|c|}{41.80}} & 49.62 \\
\hline & & & & & & & & & & & & 35.22 \\
\hline & & & & & & & & & 29.67 & 25.00 & 29.67 & 25.00 \\
\hline & & & & & & & & & 21.06 & & 21.06 & \\
\hline & & & & & & & & 17.74 & & 17.74 & & 17.74 \\
\hline & & & & & & & 14.94 & & 14.95 & & 14.94 & \\
\hline & & & & & & 12.59 & & 12.59 & & 12.59 & & 12.59 \\
\hline & & & & 8.93 & 10.61 & 8.93 & 10.61 & 8.94 & 10.61 & 5.93 & 10.61 & 8.94 \\
\hline & & & 7.53 & & 7.53 & & 7.53 & & 7.53 & & 7.53 & \\
\hline & & & & 6.34 & & 6.34 & & 6.34 & & 6.34 & & 6.34 \\
\hline & & & 5.35 & 4.50 & 5.34 & 4.50 & 5.35 & 4.50 & 5.34 & 4.50 & 5.34 & 4.50 \\
\hline & & & 3.79 & & 3.79 & & 3.79 & & 3.79 & & 3.79 & \\
\hline & & & & 3.20 & & 3.19 & & 3.20 & & 3.19 & & 3.20 \\
\hline & & & & & 2.69 & & 2.69 & & 2.70 & & 2.69 & \\
\hline & & & & & & 2.27 & & 2.27 & & 2.27 & & 2.27 \\
\hline & & & & & & & 1.91 & & 1.91 & & 1.91 & \\
\hline & & & & & & & & 1.61 & & 1.61 & & 1.61 \\
\hline & & & & & & & & & 1.36 & & 1.36 & \\
\hline & & & & & & & & & & 1.14 & & 1.14 \\
\hline & & & & & & & & & & & 0.70 & 0.81 \\
\hline
\end{tabular}


Table 4. Decision tree of a Mantiqueira ecotype dairy cattle farm, with intensive use of Mombasa grass pasture supplemented with fodder cane, for a period of 12 years (values in R \$10,000.00). Constructed using the real options theory.

\begin{tabular}{|c|c|c|c|c|c|c|c|c|c|c|c|c|}
\hline 0 & 1 & 2 & 3 & 4 & 5 & 6 & 7 & 8 & 9 & 10 & 11 & 12 \\
\hline \multirow{19}{*}{0.08} & \multirow{19}{*}{$\begin{array}{l}0.13 \\
0.00\end{array}$} & \multirow{19}{*}{$\begin{array}{l}0.21 \\
0.00 \\
0.00\end{array}$} & \multirow{19}{*}{$\begin{array}{l}0.35 \\
0.00 \\
0.00 \\
0.00\end{array}$} & \multirow{12}{*}{$\begin{array}{l}0.57 \\
0.00 \\
0.00 \\
0.00\end{array}$} & \multirow{7}{*}{0.95} & \multirow[b]{6}{*}{1.56} & \multirow[b]{5}{*}{2.60} & \multirow{5}{*}{4.30} & & \multirow{3}{*}{\multicolumn{2}{|c|}{16.64}} & 22.84 \\
\hline & & & & & & & & & & & & \multirow[b]{2}{*}{8.44} \\
\hline & & & & & & & & & & & & \\
\hline & & & & & & & & & 7.11 & & 5.11 & 000 \\
\hline & & & & & & & & & 0.00 & 0.00 & 0.00 & 0.00 \\
\hline & & & & & & & \multirow{2}{*}{0.00} & 0.00 & & 0.00 & \multirow{2}{*}{0.00} & 0.00 \\
\hline & & & & & & 0.00 & & 0.00 & 0.00 & 0.00 & & 0.00 \\
\hline & & & & & 0.00 & & \multirow{2}{*}{0.00} & & 0.00 & & \multirow[t]{2}{*}{0.00} & \\
\hline & & & & & 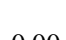 & 0.00 & & 0.00 & & 0.00 & & 0.00 \\
\hline & & & & & 0.00 & 0.00 & 0.00 & 0.00 & 0.00 & 0.00 & 0.00 & 0.00 \\
\hline & & & & & 0.00 & & 0.00 & & 0.00 & & 0.00 & \\
\hline & & & & & & 0.00 & & 0.00 & & 0.00 & & 0.00 \\
\hline & & & & 0.00 & & 0.00 & & 0.00 & 0.00 & 0.00 & 0.00 & 0.00 \\
\hline & & & & & 0.00 & & 0.00 & & 0.00 & & \multirow[t]{2}{*}{0.00} & \\
\hline & & & & & & 0.00 & & 0.00 & & 0.00 & & 0.00 \\
\hline & & & & & & & 0.00 & 0.00 & & 0.00 & 0.00 & 0.00 \\
\hline & & & & & & & & & 0.00 & & \multirow[t]{2}{*}{0.00} & \\
\hline & & & & & & & & & & 0.00 & & 0.00 \\
\hline & & & & & & & & & & & 0.00 & 0.00 \\
\hline
\end{tabular}

Table 5. Event tree of a Mantiqueira ecotype dairy cattle farm, with intensive use of Mombasa grass pasture supplemented with sorghum silage, for a period of 12 years (values in $R \$ 10,000.00$ ). Constructed using the real options theory.

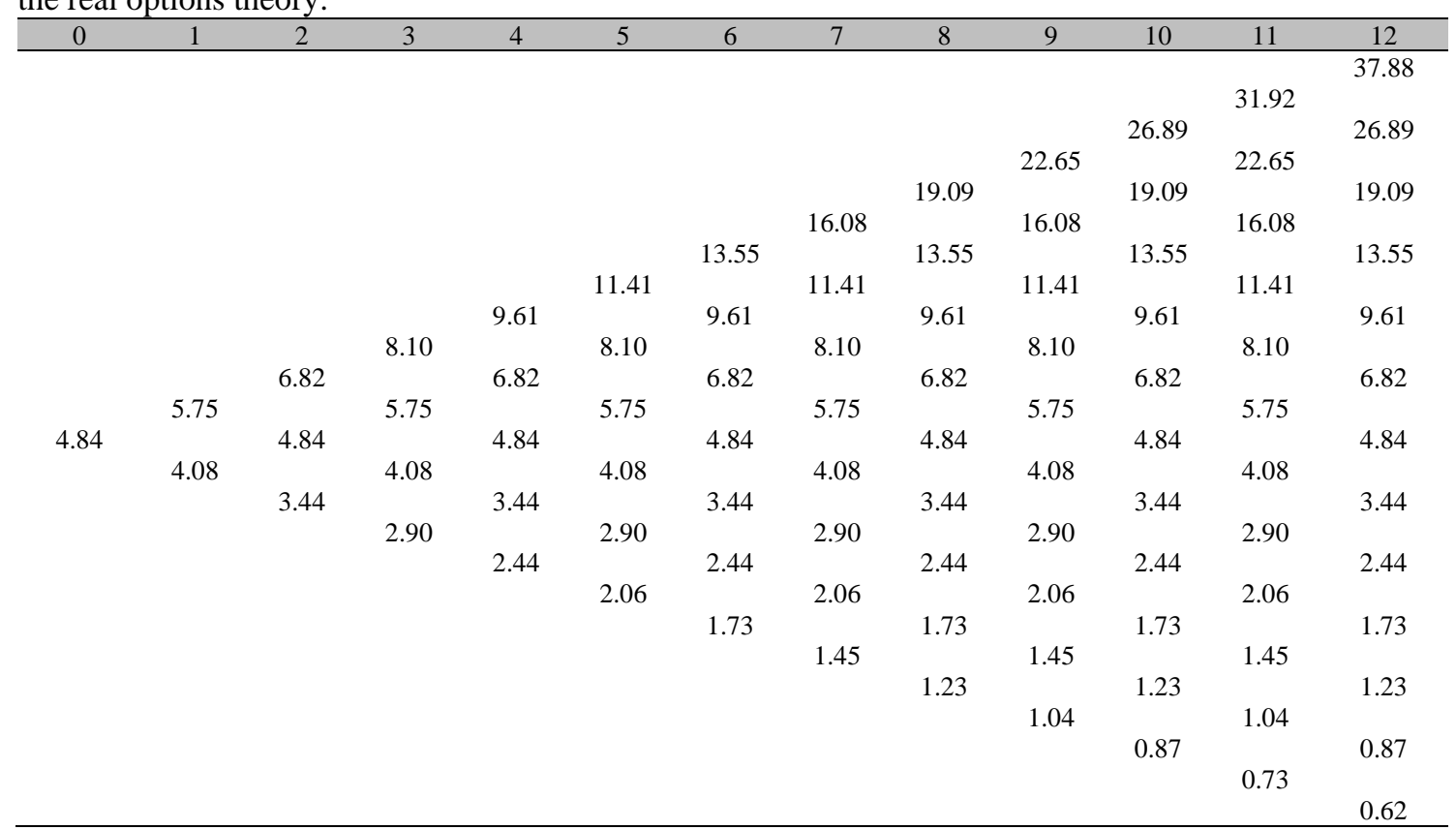




\section{Xavier et al.}

Table 6. Decision tree of a Mantiqueira ecotype dairy cattle farm, with intensive use of Mombasa grass pasture supplemented with sorghum silage, for a period of 12 years (values in R $\$ 10,000.00$ ). Constructed using the real options theory.

\begin{tabular}{|c|c|c|c|c|c|c|c|c|c|c|c|c|}
\hline 0 & 1 & 2 & 3 & 4 & 5 & 6 & 7 & 8 & 9 & 10 & 11 & 12 \\
\hline \multirow{19}{*}{0.96} & \multirow{19}{*}{$\begin{array}{l}1.28 \\
0.55\end{array}$} & \multirow{19}{*}{$\begin{array}{l}1.68 \\
7.69 \\
0.26\end{array}$} & & \multirow{9}{*}{$\begin{array}{l}2.84 \\
1.42\end{array}$} & & & & & & \multirow{3}{*}{\multicolumn{2}{|c|}{23.24}} & 28.64 \\
\hline & & & \multirow{10}{*}{$\begin{array}{l}2.19 \\
1.05 \\
3.90\end{array}$} & & \multirow{6}{*}{3.66} & \multirow[b]{5}{*}{4.74} & \multirow[b]{4}{*}{6.23} & \multirow{4}{*}{8.48} & & & & \\
\hline & & & & & & & & & & & & 17.65 \\
\hline & & & & & & & & & 12.19 & 246 & 13.98 & 984 \\
\hline & & & & & & & & & 3.29 & & \multirow{2}{*}{7.40} & \\
\hline & & & & & & & 180 & 3.27 & 285 & 5.40 & & 4.31 \\
\hline & & & & & & 2.36 & & \multirow{2}{*}{2.70} & & 1.73 & \multirow{2}{*}{0.27} & 0.37 \\
\hline & & & & & 1.86 & & 1.87 & & 1.10 & & & \\
\hline & & & & & 097 & 1.26 & 04 & 0.69 & 000 & 1.37 & \multirow{2}{*}{0.00} & 0.00 \\
\hline & & & & & & 0.27 & 0.44 & \multirow[t]{2}{*}{0.05} & 0.00 & 0.00 & & 0.00 \\
\hline & & & & & 0.17 & & 0.03 & & 0.00 & & \multirow[t]{2}{*}{0.00} & \\
\hline & & & & 1.09 & & 0.02 & & 0.00 & & 0.00 & & 0.00 \\
\hline & & & 0.068 & 0.007 & 0.01 & 0.00 & 0.00 & \multirow[t]{2}{*}{0.00} & 0.00 & 0.00 & 0.00 & 0.00 \\
\hline & & & & & 0.00 & & 0.00 & & 0.00 & & \multirow[t]{2}{*}{0.00} & \\
\hline & & & & & & 0.00 & & 0.00 & & 0.00 & & 0.00 \\
\hline & & & & & & & 0.00 & 0.00 & 0.00 & 0.00 & 0.00 & 0.00 \\
\hline & & & & & & & & & 0.00 & & 0.00 & \\
\hline & & & & & & & & & & 0.00 & \multirow{2}{*}{0.00} & 0.00 \\
\hline & & & & & & & & & & & & 0.00 \\
\hline
\end{tabular}

The values at the top of the event trees for the production systems with bulky supplementation with black oats, fodder cane, and sorghum silage were $\mathrm{R} \$ 1,036,300.00, \mathrm{R} \$ 496,205.55$, and $\mathrm{R} \$$ $378,844.30$, respectively, which are at odds with the reality of production systems in agricultural projects. However, according to Correia Neto (2009), the values that can occur never reach the extreme point of the tree because they follow reversion to the mean and are always close to the average. Moreover, according to Joaquim et al. (2015), the binomial arrangement of the values in the event tree makes it impossible to visualize the other possible values within the interval between the minimum and maximum of the selected variable.

The cells of the decision trees that have "zero" values represent the producer's decision not to expand the scale of production of the system because the price did not support the expected expenditures at that time. Additionally, in relation to the option evaluation tree (decision tree), the value obtained from the first node was the option value. The sum of this value and that of the traditional NPV (i.e., the NPV without flexibility) equaled the expanded NPV (Table 7).

Table 7. Traditional net present value, option value, and expanded net present value of dairy cattle of the Mantiqueira ecotype, with intensive use of Mombasa grass pasture using different sources of bulky supplementation, in R $\$$.

\begin{tabular}{cccc}
\hline Systems & Traditional NPV & Option Value & Expanded NPV \\
\hline Black Oats & $132.509,84$ & $8.923,15$ & $141.432,99$ \\
Fodder Cane & $63.446,07$ & 765,01 & $64.211,08$ \\
Sorghum Silage & $48.439,97$ & $9.443,10$ & $57.883,07$ \\
\hline
\end{tabular}

The expansion option generated increases of $6.73 \%, 1.21 \%$, and $19.49 \%$ for the production systems supplemented with black oats, fodder cane, and sorghum silage, respectively, suggesting that the systems can be expanded because they produce more value than the traditional production systems without flexibility do. Corroborating this premise, Brasil and Aronne (2015) analyzed the expansion option in a wind power generation project and concluded that the best decision would be to invest immediately in the plant in the expanded version, as doing so 
maximizes the use of the existing infrastructure and increases the efficiency of the financial resources applied. Using ROT, Montoro et al. (2013) evaluated the possibility of expanding a biodigester project for the treatment of bovine waste and concluded that the use of real options can assist in the expansion process of the system.

The expansion of production systems was only possible owing to the existing production scale conditions on the property, such as animal genetics, infrastructure, and management. Corroborating this statement, Costa and Santos (2019) applied ROT to the option of abandoning a modal dairy farm and concluded that, for the property in question, the abandonment option predominates without technological and management improvements. However, when improvements that promote the intensification of production systems were adopted, they offered alternatives, such as the expansion and processing of the milk produced, thus ensuring the success of agricultural activity.

This analysis showed that ROT is an important tool for increasing capacity to measure the value of an activity and helping the producer make decisions taking into account the flexibilities and uncertainties in the project. Corroborating this statement, Muller (2018) used ROT to assess the effect of risk on investment decisions for dairy farmers in the Netherlands, where the NPV of the investment was negative in all cases. However, ROT showed that better values could be obtained if the farmer had the flexibility to choose when to invest. Thus, this result emphasizes the importance of considering existing flexibilities when evaluating a project.

Rutten et al. (2018) also used ROT to analyze the feasibility of delaying automated sensor investments in a dairy farm. For the estrus detection sensor, the decision to invest immediately proved to be the most feasible, whereas, for the automated body condition sensor, the best decision was to delay investment by five years to obtain better information about the sensor and potential future improvements to the technology, resulting in the availability of important information for the producer's decision making. The analysis of real options is complex and requires advanced mathematical knowledge. For this reason, some managers prefer to use simpler methods even though they are not efficient. However, approaches such as the binomial model are considered viable as well as intuitive for practical application.

\section{CONCLUSION}

By increasing the ability to measure the real value of dairy activity, ROT can be used in risk management studies of dairy activity to assist farmers in decision making.

\section{REFERENCES}

ANUÁRIO do leite. [São Pauo]: Embrapa, 2019. Disponível em: https://www.embrapa.br/gado-deleite. Acesso em: 13 dez. 2019.

BRASIL, H.G.; ARONNE, A.V. Aplicação da teoria de opções em projeto de geração eólica de energia: opções de adiamento e de expansão. In: SIMPÓSIO INTERNACIONAL DE GESTÃO DE PROJETOS, INOVAÇÃO E SUSTENTABILIDADE, 4., 2015, São Paulo. Anais... São Paulo: [s.n.], 2015. p.17.

$\begin{array}{lcr}\text { CENSO Agropecuário. Rio de Janeiro: } & \text { Rio }\end{array}$ http://www.sidra.ibge.gov.br/. Acessdo em: 1 out. 2018.

COPELAND, T.; ANTIKAPAROV, V. Opções reais - um novo paradigma para reinventar a avaliação de investimentos. Rio de Janeiro: Campus, 2001. 384p.

CORREIA NETO, J.F. Elaboração e avaliação de projetos de investimentos: considerando o risco. Rio de Janeiro: Campus, 2009. 288p.

COSTA, I.R.B.; SANTOS, D.F.L. Viabilidade econômica de uma propriedade leiteira modal com opções reais. Custos @gronegócio online, v.15, p.81-112, 2019.

DIXIT, A.K.; PINDYCK, R.S. Investment under uncertainty. New Jersey: Princeton University Press, 1994. 488p.

GUARAGNA, G.P.; GAMBINI, L.P.; FIGUEIREDO, A.L. Mantiqueira: 30 anos depois. Nova Odessa: Instituto de Zootecnia, Secretaria de Agricultura e Abastecimento de São Paulo, 1984. 30p.

ÍNDICES gerais. Rio de Janeiro: FVG, 2019. Disponível em: https://portal.fgv.br/. Acessado em: 20 dez. 2018. 
JOAQUIM, M.S.; SOUZA, A.N.; PEREIRA, R.S.; ANGELO, H. Aplicação da teoria das opções reais na análise de investimentos em sistemas agroflorestais. Cerne, v.21, p.439-477, 2015.

MONTORO, S.B.; SANTOS, D.F.L.; JUNIOR, J.L. Análise econômica de investimentos que visam à produção de biogás e biofertilizante por meio de iodigestão anaeróbia na bovinocultura de corte. Rev. Eletr. Mestrado Prof. Adm. Univ. Potiguar, v.5, p.23-34, 2013.

MULLER, W. Simulated real option approach to investment decisions of Dutch dairy farmers. 2018. 68f. Dissertação (Mestrado em Economia Empresarial) - Universidade de Wageningen, Holanda.

NARDELLI, P.M. Análise de um projeto agroindustrial utilizando a teoria de opções reais. 2009. 81f. Dissertação (Mestrado Profissional em Gestão Estratégia em Negócios) - Universidade Federal Rural do Rio de Janeiro, Seropédica, RJ.

PADDOCK, J.; SIEGEL, D.; SMITH, J. Option valuation on claims on physical assets: the case of offshore petroleum leases. Q. J. Econ., v.103, p.479-508, 1988 .
PERES, A.A.C. Viabilidade técnica e econômica de sistemas de produção a pasto para vacas em lactação sob manejo rotacionado. 2006. $181 \mathrm{f}$. Tese (Doutorado em Ciência Animal) Universidade Estadual do Norte Fluminense, Campos dos Goytacazes, RJ.

PESQUISA agropecuária municipal. Rio de Janeiro: IBGE, 2017. Disponível em: http://www.sidra.ibge.gov.br/. Acessado em: 01 out. 2018.

RUTTEN, C.J.; STETNEVELD, W.; OUDE LANSINK, A.G.J.M.; HOGEVEEN, H. Delaying investments in sensor technology: the rationality of dairy farmers' investment decisions illustrated within the framework of real options theory. $J$. Dairy Sci., v.101, p.7650-7660, 2018.

TAXA Selic. Brasília: Banco Central do Brasil, $2019 . \quad$ Disponível em: https://www.bcb.gov.br/controleinflacao/taxaseli c . Acessado em: 10 mar. 2019. 